Article

\title{
Rapid Jatropha-Castor Biodiesel Production with Microwave Heating and a Heterogeneous Base Catalyst Nano- $\mathrm{Ca}(\mathrm{OH})_{2} / \mathrm{Fe}_{3} \mathrm{O}_{4}$
}

\author{
Ken-Lin Chang ${ }^{1}$, Yuan-Chung Lin ${ }^{1,2, *}$, Syu-Ruei Jhang ${ }^{1}$, Way Lee Cheng ${ }^{3}$, Shang-Cyuan Chen ${ }^{1}$ \\ and Sung-Yuan Mao ${ }^{1}$ \\ 1 Institute of Environmental Engineering, National Sun Yat-sen University, Kaohsiung 804, Taiwan; \\ klchang@mail.nsysu.edu.tw (K.-L.C.); jgvm5028@gmail.com (S.-R.J.); Shang.Quan0203@gmail.com (S.-C.C.); \\ skysean33@gmail.com (S.-Y.M.) \\ 2 Ph.D. Program in Toxicology, College of Pharmacy, Kaohsiung Medical University, Kaohsiung 80708, Taiwan \\ 3 Mechanical Engineering, Texas A\&M University at Qatar, Qatar Foundation Education City, Doha, Qatar; \\ cheng-wl@alum.northwestern.edu \\ * Correspondence: yclin@faculty.nsysu.edu.tw; Tel.: +886-7-525-2000 (ext. 4412); Fax: +886-7-525-4412
}

Academic Editors: Tian-Yi Ma, Jian-Rong (Jeff) Li and Cláudia Gomes Silva

Received: 31 March 2017; Accepted: 19 June 2017; Published: 4 July 2017

\begin{abstract}
In this study, a nano- $\mathrm{Ca}(\mathrm{OH})_{2} / \mathrm{Fe}_{3} \mathrm{O}_{4}$ catalyst was used to produce biodiesel from a 1:1 mixed jatropha-castor oil. By loading $\mathrm{Ca}(\mathrm{OH})_{2}$ onto $\mathrm{Fe}_{3} \mathrm{O}_{4}$ nanoparticles, it increased the specific surface area by almost $40 \%$, which improved the catalytic activity as it provided a larger area for the reactants to interact. The main purpose of mixing jatropha oil with castor oil was to lower the viscosity of the castor oil. The transesterification reaction was carried out at elevated temperature, using a microwave heating system. Moreover, it was shown that the preferred reaction conditions are using high temperature and short reaction duration. The optimized yield of methyl ester was $95 \%$, achieved by using a catalyst with a Ca:Fe ratio of 7:1, temperature of $65^{\circ} \mathrm{C}$, methanol/oil ratio of 12:1, and reaction time of $35 \mathrm{~min}$. The catalyst was shown to be reusable, easily recyclable, and its activity was very stable. Only $2 \%$ of the catalyst was lost, and the yield was $3 \%$ lower after ten successive applications. The solid, magnetic base catalyst could be easily separated from the reaction products, unlike homogeneous catalysts.
\end{abstract}

Keywords: nano- $\mathrm{Ca}(\mathrm{OH})_{2} / \mathrm{Fe}_{3} \mathrm{O}_{4}$; biodiesel; microwave; heterogeneous catalyst

\section{Introduction}

Biodiesel is one of the most feasible alternatives to petroleum-based diesel as it is renewable and compatible with current economic and technological infrastructures. However, the cost of biodiesel is about $150 \%$ that of petroleum-based diesel, which is a major drawback for wide-scale biodiesel applications, mainly due to more expensive feedstock oil [1]. Biodiesel can simultaneously reduce various engine emissions: carbon monoxide $(\mathrm{CO})$, hydrocarbon $(\mathrm{HC})$, particulate matter $(\mathrm{PM})$, polycyclic aromatic hydrocarbon (PAH), and sulfur dioxide $\left(\mathrm{SO}_{2}\right)$ [2-8]. It also has a higher cetane number, which improves the combustion quality, higher flash point, and better lubrication properties than conventional diesel fuel. Biodiesel is the next-generation engine fuel that can meet the stricter emission regulations set by the Environmental Protection Agency in the United States $[9,10]$. Biodiesel is mainly produced by transesterification of triglycerides of fatty acids with methanol. The reaction is extremely slow under room conditions [11-13]. Most fatty acid methyl esters (FAMEs) are synthesized using a homogeneous catalyst such as sodium or potassium hydroxide and sodium methoxide $[14,15]$. However, there are many disadvantages with homogeneous catalysts such as 
saponified products resulting from free fatty acid in the feedstock, problematic post-treatment such as the separation of the catalyst from the FAMEs, and post-treatment pollution $[16,17]$. In particular, the complicated post-treatment process deems the application of homogeneous catalysts as impractical and inefficient [18,19], especially for industrial-scale applications. Research has been conducted for finding a heterogeneous catalyst which can be easily separated from the products at the end of the reaction and without the need for complicated post-treatment processing [20]. Many solid base catalysts have been developed to date. These catalysts include several kinds of chemical compounds such as calcium oxide [21-23], alkali-doped metal oxides such as $\mathrm{CaO}-\mathrm{Al}_{2} \mathrm{O}_{3}, \mathrm{~K}_{2} \mathrm{CO}_{3} / \mathrm{Al}_{2} \mathrm{O}_{3}$, and $\mathrm{Ca}(\mathrm{OH})_{2}-\mathrm{Fe}_{3} \mathrm{O}_{4}$, and supported ones such as sodium aluminate and calcium ethoxide [14,24-27]. However, it is known that the solid catalysts may have limited stability, recovery rate, and catalytic activity. The limitations of solid alkali catalysts can be overcome by using nanoscale magnetic alkali catalysts. These catalysts can be recovered at the end of the transesterification reaction by applying an external magnetic field. Also, most nano-sized solid catalysts are highly dispersible, which promotes interactions between the reactants on the catalyst surface. In particular, iron oxide $\left(\mathrm{Fe}_{3} \mathrm{O}_{4}\right)$ magnetic particles have been studied considerably for catalytic applications in biodiesel production [28-31]. Dai et al. prepared $\mathrm{LiAlO}_{2}$ and $\mathrm{Li}_{2} \mathrm{TiO}_{3}$ as solid-state reaction catalysts, and applied them to biodiesel production using methanol and soybean oil. Because of the biphasic function, the catalysts could be easily separated. $\mathrm{LiAlO}_{2}$ and $\mathrm{Li}_{2} \mathrm{TiO}_{3}$ may be simply recovered and reused without inactivation [32,33]. Tang et al. studied magnetic nanoparticle catalysts was prepared by loading calcium aluminate. The optimum conditions were obtained when the $\mathrm{Ca} / \mathrm{Fe}$ molar ratio of $5: 1$ and the yield of biodiesel reached $98.71 \%$ after a $6 \mathrm{~h}$ reaction at $600{ }^{\circ} \mathrm{C}$ [14]. Hu et al. developed the $\mathrm{KF} / \mathrm{CaO}-\mathrm{Fe}_{3} \mathrm{O}_{4}$ solid base catalyst that had a recovery rate higher than $90 \%$ [30]. The studies reported that the biodiesel yield was greater than $95 \%$ with transesterification being carried out at $65^{\circ} \mathrm{C}$, a methanol/oil ratio of $12: 1$, and $4 \mathrm{wt} \%$ of catalyst loading. Liu et al. also proposed the $\mathrm{Ca}(\mathrm{OH})_{2} / \mathrm{Fe}_{3} \mathrm{O}_{4}$ catalyst with a recovery rate of $91 \%$ [31]. The optimized yield was $99 \%$ with a reaction time of $4 \mathrm{~h}$ using a "new, unused" catalyst. The reported yield was $90 \%$ and $70 \%$ after 5 and 10 catalyst applications, respectively. Microwave heating is being studied to improve the process as it can increase the reaction rate, yield, and purity of the products. Azcan and Danisman reported that the transesterification of cottonseed oil with methanol and potassium hydroxide could achieve a $90 \%$ yield level in $7 \mathrm{~min}$ with microwave heating, as opposed to $30 \mathrm{~min}$ with conventional heating [34]. Suppalakpanya et al. reported that with microwave heating and $\mathrm{H}_{2} \mathrm{SO}_{4} /$ free fatty acid as the catalyst, the reaction time could be shortened by $3 \mathrm{~h}$ or more for palm biodiesel with an $80 \%$ yield [35]. The same authors also reported a reaction time of 5 min with microwave heating versus $1 \mathrm{~h}$ with conventional heating if a base catalyst, potassium hydroxide, was used [36]. Koberg et al. reported an optimized yield of over $99 \%$ for converting waste cooking oil into biodiesel, using $\mathrm{SrO}$ as the catalyst and applying $1100 \mathrm{~W}$ of microwave heating [37]. The authors reported that it took less than 1 minute to reach a $99 \%$ yield of biodiesel. In short, it has been shown that microwave heating can significantly accelerate the transesterification reaction, improving the yield and lowering the production cost due to less energy consumption. Previous studies have shown that the properties of the feedstock oil affect the quality of the biodiesel [38-40]. Jatropha curcas is a plant in the Euphorbiaceae family and is commonly grown in tropical and subtropical regions such as India, South-East Asia, and Latin America [41]. The plant has high oil content [42]. Moreover, jatropha oil is inedible, and thus it is a low-cost alternative to edible oils such as soybean oil or palm oil as the raw material for biodiesel production. Meanwhile, castor oil, poisonous for human consumption, is derived from the seeds of Ricinus Communis. It is mostly used as a lubricant. Castor oil can be used as the feedstock oil in biodiesel production [43]. The oil content of castor beans is as high as $70 \%$. However, both jatropha oil and castor oil cannot be used directly in diesel engines as they are too viscous (especially true for castor oil). Moreover, jatropha oil has a very high acid value that might cause corrosion and other damage if used directly in diesel engines.

In this study, a heterogeneous magnetic base catalyst, nano- $\mathrm{Ca}(\mathrm{OH})_{2} / \mathrm{Fe}_{3} \mathrm{O}_{4}$, is applied in the transesterification reaction using a 1:1 mixed jatropha-castor oil as the feedstock oil. 
The transesterification reaction is undertaken with microwave heating. The microstructure and morphology of the catalyst are assessed with gas chromatographic and mass spectroscopic analysis. The effects of the catalyst composition, reaction temperature, reaction duration, and methanol/oil molar ratio on the yield of biodiesel are then examined. The stability of the catalyst and its effects on yield levels are measured and discussed as well. The impacts of microwave heating on transesterification is then analyzed and compared with conventional heating methods.

\section{Results and Discussion}

\subsection{Characteristics of the Catalyst}

Figure 1 shows the $\mathrm{X}$-ray diffractometer $(\mathrm{XRD})$ pattern of the heterogeneous base catalyst, nano- $\mathrm{Ca}(\mathrm{OH})_{2} / \mathrm{Fe}_{3} \mathrm{O}_{4}$. The analysis of the synthesized nano- $\mathrm{Ca}(\mathrm{OH})_{2} / \mathrm{Fe}_{3} \mathrm{O}_{4}$ catalyst had the characteristic peak at the $2 \theta$ value at $18.0^{\circ}$ and $63.0^{\circ}$ which were the characteristic peak of $\mathrm{Ca}(\mathrm{OH})_{2}$ (JCPDS Card No. 044-1481). The peaks that occurred at $2 \theta$ values of $18.0^{\circ}, 30.3^{\circ}, 35.7^{\circ}, 43.4^{\circ}, 53.9^{\circ}$, $57.4^{\circ}$, and $63.0^{\circ}$, corresponds to $\mathrm{Ca}(\mathrm{OH})_{2}, \mathrm{Fe}_{3} \mathrm{O}_{4}, \mathrm{Fe}_{3} \mathrm{O}_{4}, \mathrm{Fe}_{3} \mathrm{O}_{4}, \mathrm{CaO}, \mathrm{Fe}_{3} \mathrm{O}_{4}, \mathrm{Ca}(\mathrm{OH})_{2}$, respectively. The composition of the catalyst was verified with an Energy-Dispersive Spectroscopy (EDS) mounted on an Environmental Scanning Electron Microscope (ESEM). Figure 2 displays the Energy-Dispersive Spectroscopy (EDS) spectrum of the nano- $\mathrm{Ca}(\mathrm{OH})_{2} / \mathrm{Fe}_{3} \mathrm{O}_{4}$ catalyst. For the catalyst synthesized by $\mathrm{CaCl}_{2}$ and $\mathrm{Fe}_{3} \mathrm{O}_{4}$ at a ratio of $7: 1$, the molar ratio of $\mathrm{Ca}(\mathrm{OH})_{2}$ to $\mathrm{Fe}_{3} \mathrm{O}_{4}$ of the as-synthesized catalyst was about 7:1. Previous studies showed that there is an optimal amount of calcium in the catalyst [30,31]. If the Ca:Fe ratio is too small, the activity of the catalyst is too low, and the catalyst is ineffective. On the other hand, as $\mathrm{Ca}(\mathrm{OH})_{2}$ tends to aggregate, the specific surface area will be reduced if the $\mathrm{Ca}: \mathrm{Fe}$ ratio is too high.

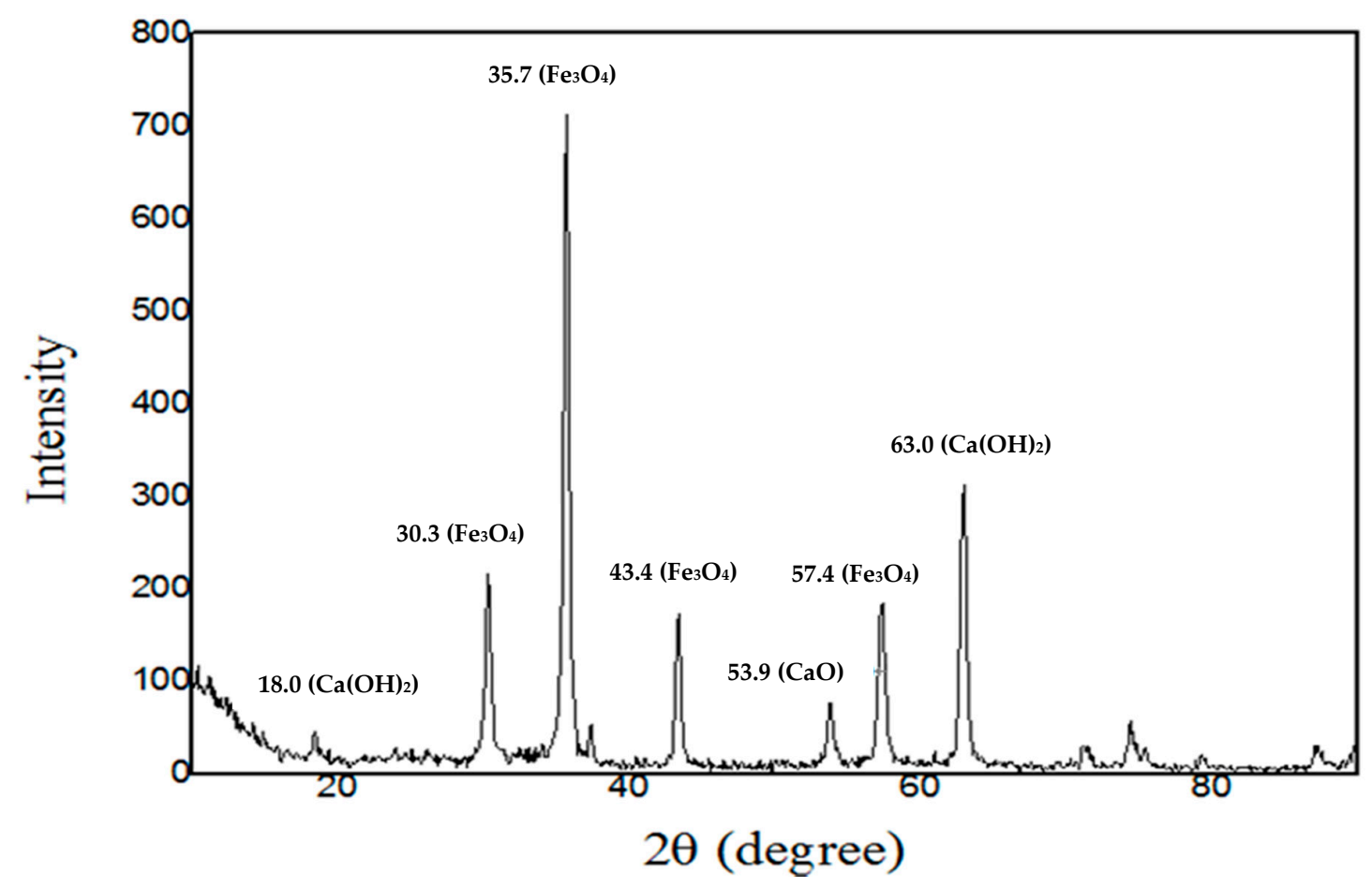

Figure 1. The X-ray diffractometer (XRD) pattern of the synthesized catalyst, nano- $\mathrm{Ca}(\mathrm{OH})_{2} / \mathrm{Fe}_{3} \mathrm{O}_{4}$.

Figure 3 shows the grain structure of the catalyst captured by the ESEM. The initial size of the grain was between $40 \mathrm{~nm}$ and $55 \mathrm{~nm}$. After repeated applications, the grain size increased to between $65 \mathrm{~nm}$ and $90 \mathrm{~nm}$. Table 1 compares the grain structure of iron oxide, both with and without the inclusion of $\mathrm{Ca}(\mathrm{OH})_{2}$. The grain size is slightly larger by about $2 \%$ for the $\mathrm{Fe}_{3} \mathrm{O}_{4}$ with $\mathrm{Ca}(\mathrm{OH})_{2}$. 
Meanwhile, the specific surface area is $40 \%$ higher with the addition of $\mathrm{Ca}(\mathrm{OH})_{2}$. Higher specific surface area enhances the contact between the chemicals during transesterification and thus increases the effectiveness of the catalyst.

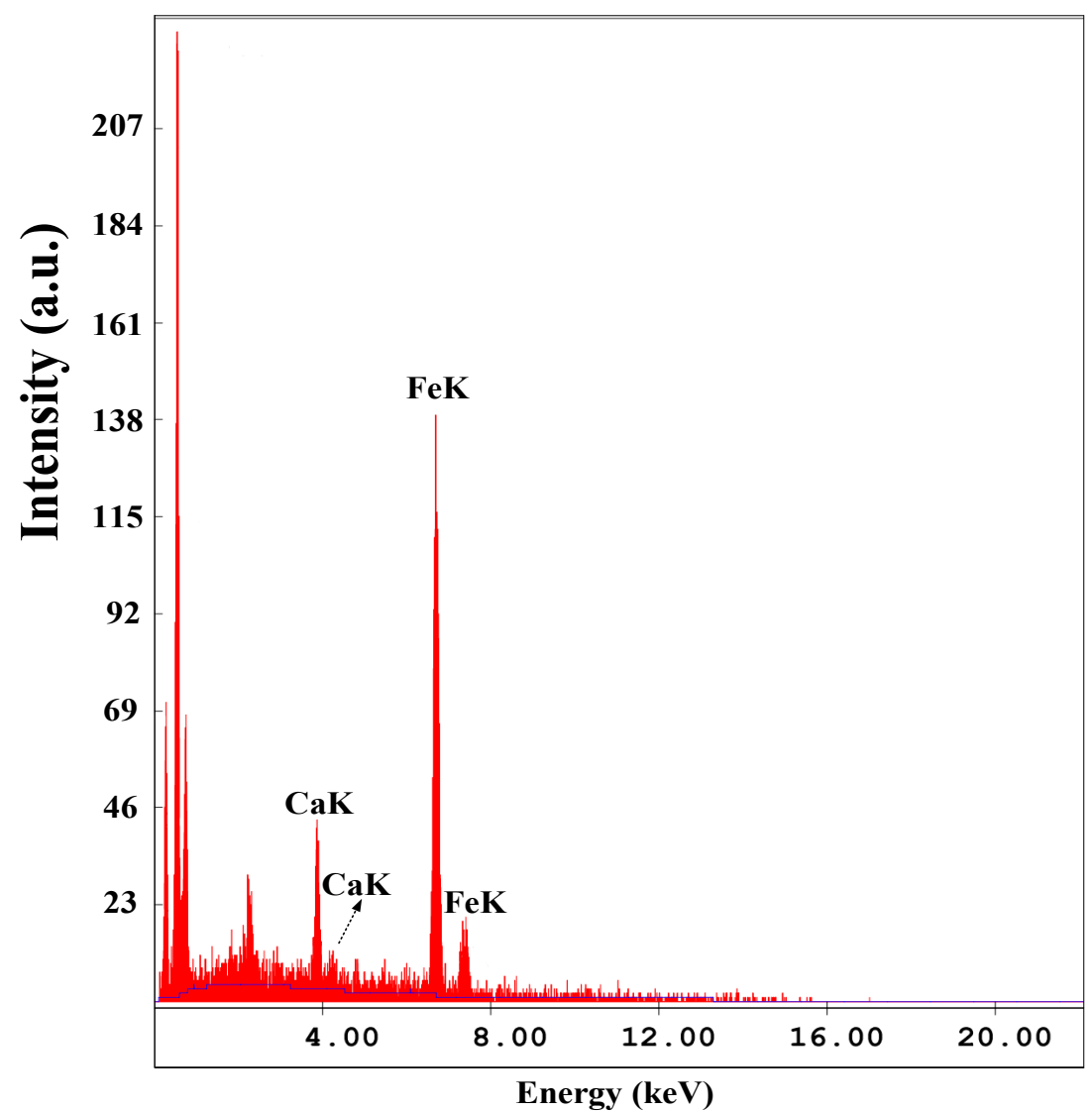

Figure 2. The Energy-Dispersive Spectroscopy (EDS) spectrum of the catalyst.

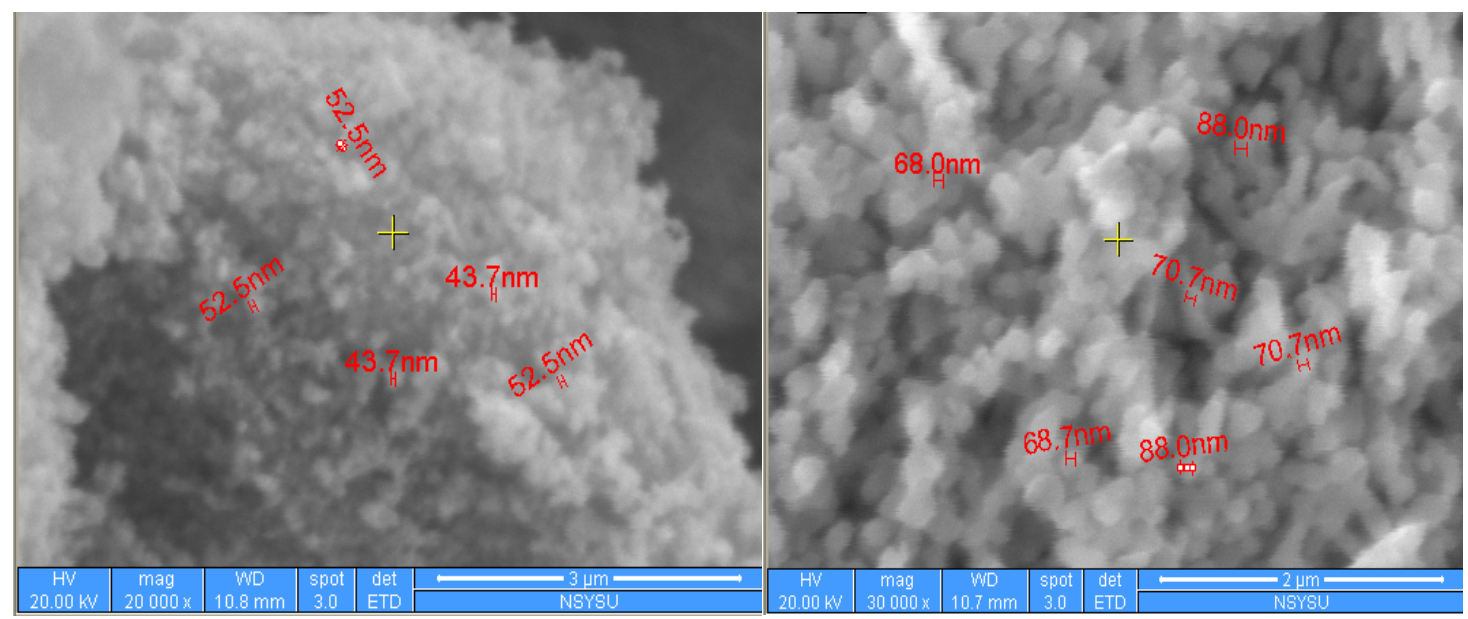

(a) Before use

(b) After ten applications

Figure 3. The material structure of the catalyst, captured by the Environmental Scanning Electron Microscope (ESEM). Plot (a) represents the initial size of the grain was between $40 \mathrm{~nm}$ and $55 \mathrm{~nm}$. Plot (b) shows the grain size increased to between $65 \mathrm{~nm}$ and $90 \mathrm{~nm}$ after repeated applications. 
Table 1. Comparison of the grain structure and specific surface area of $\mathrm{Fe}_{3} \mathrm{O}_{4}$ and nano- $\mathrm{Ca}(\mathrm{OH})_{2} / \mathrm{Fe}_{3} \mathrm{O}_{4}$.

\begin{tabular}{ccc}
\hline Catalyst & Specific Surface Area $\left(\mathbf{m}^{3} / \mathbf{g}\right)$ & Grain Size $(\mathbf{n m})$ \\
\hline $\mathrm{Fe}_{3} \mathrm{O}_{4}$ & 24.8169 & 25.6254 \\
nano- $\mathrm{Ca}(\mathrm{OH})_{2} / \mathrm{Fe}_{3} \mathrm{O}_{4}$ & 34.7892 & 26.0871 \\
\hline
\end{tabular}

\subsection{Effects of the Ca:Fe Ratio on the Nano- $\mathrm{Ca}(\mathrm{OH})_{2} / \mathrm{Fe}_{3} \mathrm{O}_{4}$ Catalyst and Methanol/Oil Ratio}

Figure 4 shows the effect of the catalyst Ca:Fe ratio on the yield of biodiesel, for transesterification reactions that were carried out at $65^{\circ} \mathrm{C}$ and with a methanol/oil ratio of 12:1. The figure shows that there exists an optimal Ca:Fe ratio, which is 7:1, with a yield of about $95 \mathrm{wt} \%$. The chemical and physical properties of the feedstock oils were showing in Table 2. Figure 5 illustrates the yield of FAME for Runs 1 through 8 shown in Table 3, with catalysts of different Ca:Fe ratios. As in the case shown in Figure 4, a catalyst with a Ca:Fe ratio of 7:1 always produced the highest yield for a given set of methanol/oil ratio, temperature, and reaction time. The maximum yield was obtained with a temperature of $70{ }^{\circ} \mathrm{C}$ and a reaction time of $30 \mathrm{~min}$, for methanol/oil ratios of both 9:1 and 15:1 (Runs 3 and 7, respectively). The effects of the methanol/oil ratio on the yield of FAME under different experimental conditions can be observed by comparing the results in Runs 1 through 4 (methanol/oil ratio of 9:1) against those in Runs 5 through 8 (methanol/oil ratio of 15:1). The yield was lower at $60{ }^{\circ} \mathrm{C}$ due to an incomplete transesterification reaction (Runs 1, 2, 5, and 6). On the other hand, a longer reaction time and a high temperature $\left(70^{\circ} \mathrm{C}\right.$ ) (Runs $3,4,7$, and 8 ) induced the reverse reaction. The viscosity of the feedstock oil is likely to increase at high temperature as well. High temperature also increased the evaporation rate of methanol. Therefore, the yield for Run 8 was lowest and in the $70 \mathrm{wt} \%$ levels among the cases shown in Figure 5. Comparing the yields from Runs 2 and 3, it can be observed that the yield at a high temperature and shorter reaction time was better than the yield observed at a lower temperature but longer reaction time. This observation shows that the temperature is the dominating factor on the final yield of biodiesel. Eevera et al. pointed out that hydrolysis occurs if the reaction time is too long, which increases the water content and stimulates the production of fatty acid, which in turns lowers the yield of FAME [44]. Moreover, when there is too much methanol, the degeneration of the yield of FAME is probably caused by a relatively low concentration of catalyst in the reaction system caused by excess methanol.

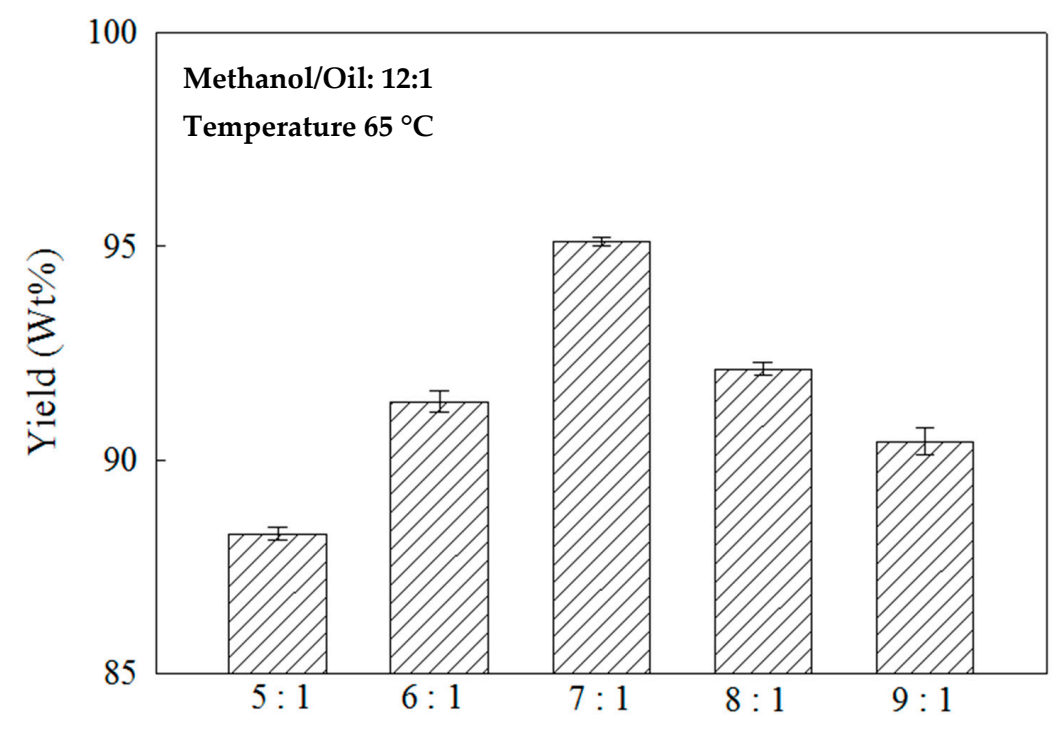

$\mathrm{Ca}:$ Fe Ratio

Figure 4. Effects of the catalyst Ca:Fe ratio on the yield with a methanol/oil molar ratio of 12:1. 
Table 2. Chemical and physical properties of the feedstock oils.

\begin{tabular}{cccccc}
\hline & Acidity $(\mathbf{m g ~ K O H} / \mathrm{g})$ & $S V(\mathbf{m g ~ K O H} / \mathrm{g})$ & $\mathrm{MW}(\mathrm{g} / \mathrm{mole})$ & Viscosity $\left(\mathrm{mm}^{2} / \mathbf{s}\right)$ & Density $\left(\mathbf{k g} / \mathbf{m}^{3}\right)$ \\
\hline Jatropha Oil & 2.10 & 195.12 & 861.01 & 38.10 & 921 \\
Castor Oil & 0.64 & 182.37 & 921.20 & 84.00 & 920 \\
\hline \multicolumn{5}{r}{ SV: Saponification Value; MW: Averaged Molecular Weight. }
\end{tabular}
$S V$ : Saponification Value; $M W$ : Averaged Molecular Weight.

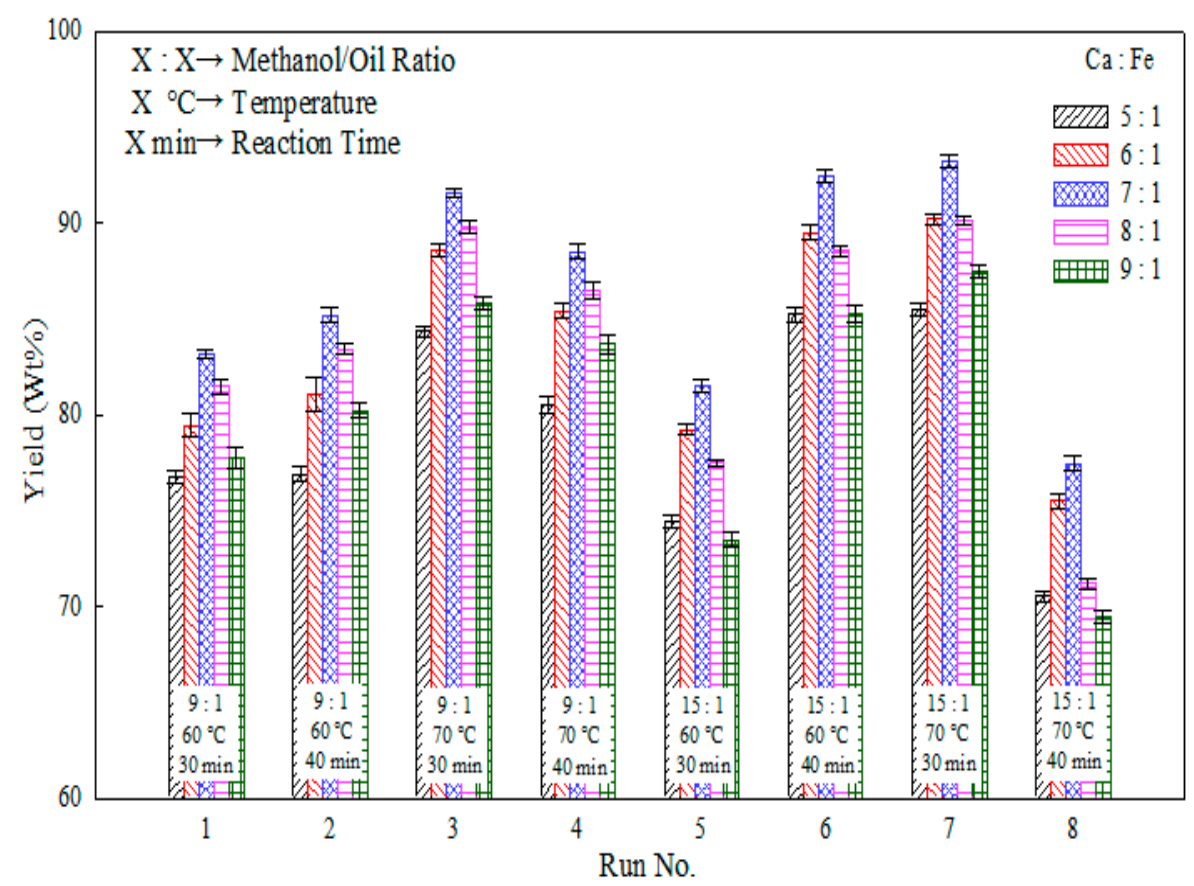

Figure 5. The yield of fatty acid methyl esters (FAME) for Runs 1 to 8 in Table 3.

Table 3. Testing conditions in this study.

\begin{tabular}{ccccc}
\hline Run No. & Methanol/Oil Ratio & Heating Temperature $\left({ }^{\circ} \mathbf{C}\right)$ & Reaction Time $(\mathbf{m i n})$ & Yield (wt \%) \\
\hline 1 & $9: 1$ & 60 & 30 & 83.4 \\
2 & $9: 1$ & 60 & 40 & 85.3 \\
3 & $9: 1$ & 70 & 30 & 91.6 \\
4 & $9: 1$ & 70 & 40 & 88.9 \\
5 & $15: 1$ & 60 & 30 & 81.2 \\
6 & $15: 1$ & 60 & 40 & 92.4 \\
7 & $15: 1$ & 70 & 30 & 93.5 \\
8 & $15: 1$ & 70 & 40 & 77.8 \\
9 & $2: 1$ & 65 & 35 & 0 \\
10 & $22: 1$ & 65 & 35 & 24.1 \\
11 & $12: 1$ & 10 & 35 & 0 \\
12 & $12: 1$ & 120 & 35 & 8.2 \\
13 & $12: 1$ & 65 & 6 & 0 \\
14 & $12: 1$ & 65 & 65 & 43.8 \\
15 & $12: 1$ & 65 & 35 & 94.8 \\
16 & $12: 1$ & 65 & 35 & 95.2 \\
\hline
\end{tabular}




\subsection{Effects of Temperature and Reaction Time}

The impact of temperature on the yield of FAME under different experimental conditions can be seen by comparing the results in Runs $1,2,5$, and $6\left(60^{\circ} \mathrm{C}\right)$ against those in Runs $3,4,7$, and 8 $\left(70{ }^{\circ} \mathrm{C}\right)$ in Figure 5 . At $60^{\circ} \mathrm{C}$, a higher yield can be obtained by increasing the methanol/oil ratio and lengthening the reaction time (Run 6). The longer reaction period is needed to ensure a complete transesterification reaction at low-to-moderate temperatures. Meanwhile, maintaining a methanol/oil ratio of 9:1 and a longer reaction time improves the yield of FAME. However, for a heating time of 30 min (i.e., Run 1 versus Run 5), a lower methanol/oil ratio will improve the yield. Therefore, if the reaction takes place at a sub-optimal condition, lowering the methanol/oil ratio will improve mixing between the oil and catalyst, which in turns raises the yield. Meanwhile, when the temperature was raised to $70{ }^{\circ} \mathrm{C}$, the highest yield was obtained using a 15:1 methanol/oil ratio and a heating time of $30 \mathrm{~min}$ (Run 7). Even with a 9:1 methanol/oil ratio, a reaction time of $30 \mathrm{~min}$ also resulted in better yield at $70{ }^{\circ} \mathrm{C}$ (Run 3). This result suggests that at a higher temperature, it is desired to shorten the reaction time as hydrolysis might otherwise occur and reduce the yield of FAME.

The effects of the reaction time on the yield of FAME can be seen by comparing the results in Runs 1, 3, 5, and 7 (30 $\mathrm{min}$ ) against those in Runs 2, 4, 6, and 8 (40 min) in Figure 5. For $30 \mathrm{~min}$ of heating, the optimal condition observed in the experiments is $70{ }^{\circ} \mathrm{C}$ and a methanol/oil ratio of 15:1 (Run 7). A higher methanol/oil ratio raises the yield of biodiesel at high temperature as extra methanol is needed to compensate for faster evaporation at an elevated temperature. The figure shows that higher temperature improves the yield for a given methanol/oil ratio because of the complete transesterification reaction at high temperature (Run 3 versus Run 7). In contrast, for a longer reaction time (40 $\mathrm{min}$ ), the highest yield is obtained under the conditions of a reaction temperature of $60^{\circ} \mathrm{C}$ and a methanol/oil ratio of 15:1 (Run 6). Figure 5 also shows that under the condition of a high methanol/oil ratio, high temperature and a longer reaction time will significantly reduce the yield (Run 8). The vast reduction in final biodiesel yield for Run 8 is most likely due to intense evaporation of methanol and the hydrolysis of biodiesel. However, for a small methanol/oil ratio of 9:1, higher temperature leads to better yield due to the complete reaction (Run 2 versus Run 4).

\subsection{Discussion of Response Surface Methodology on Biodiesel Production}

Figure 6 displays the results from the Response Surface Methodology, using a catalyst with a Ca:Fe ratio of 7:1 and the mixed feedstock oil. The figure shows the yield of biodiesel using the maximum and minimum values for each of the three factors: methanol/oil ratio (2:1 versus 22:1, Runs 9 and 10), temperature $\left(10{ }^{\circ} \mathrm{C}\right.$ versus $120^{\circ} \mathrm{C}$, Runs 11 and 12) and reaction time (6 min versus $65 \mathrm{~min}$, Runs 13 and 14). When using the minimum methanol/oil ratio (2:1, Run 9), transesterification did not occur at all as there were insufficient interactions between the reactants and the catalyst. Similarly, when the temperature or reaction time was minimized (Runs 11 and 13), there was no reaction at all due to an insufficient amount of energy. On the other hand, when maximizing the methanol/oil ratio (22:1, Run 10), the yield was only $24.1 \mathrm{wt} \%$, compared to yields in the range of 60 to $90 \mathrm{wt} \%$ shown in Figure 5. The low yield level is due to the strong reverse reaction between FAME and methanol. High temperature (Run 12) reduces the yield significantly because of substantial methanol evaporation, which reduces the interactions between the chemical species. Prolonged reaction time (65 min, Run 14) causes hydrolysis of the biodiesel, which lowers the yield as well. However, comparing the results from Runs 10,12, and 14, it can be seen that temperature is the dominating factor that affects the yield of biodiesel. 

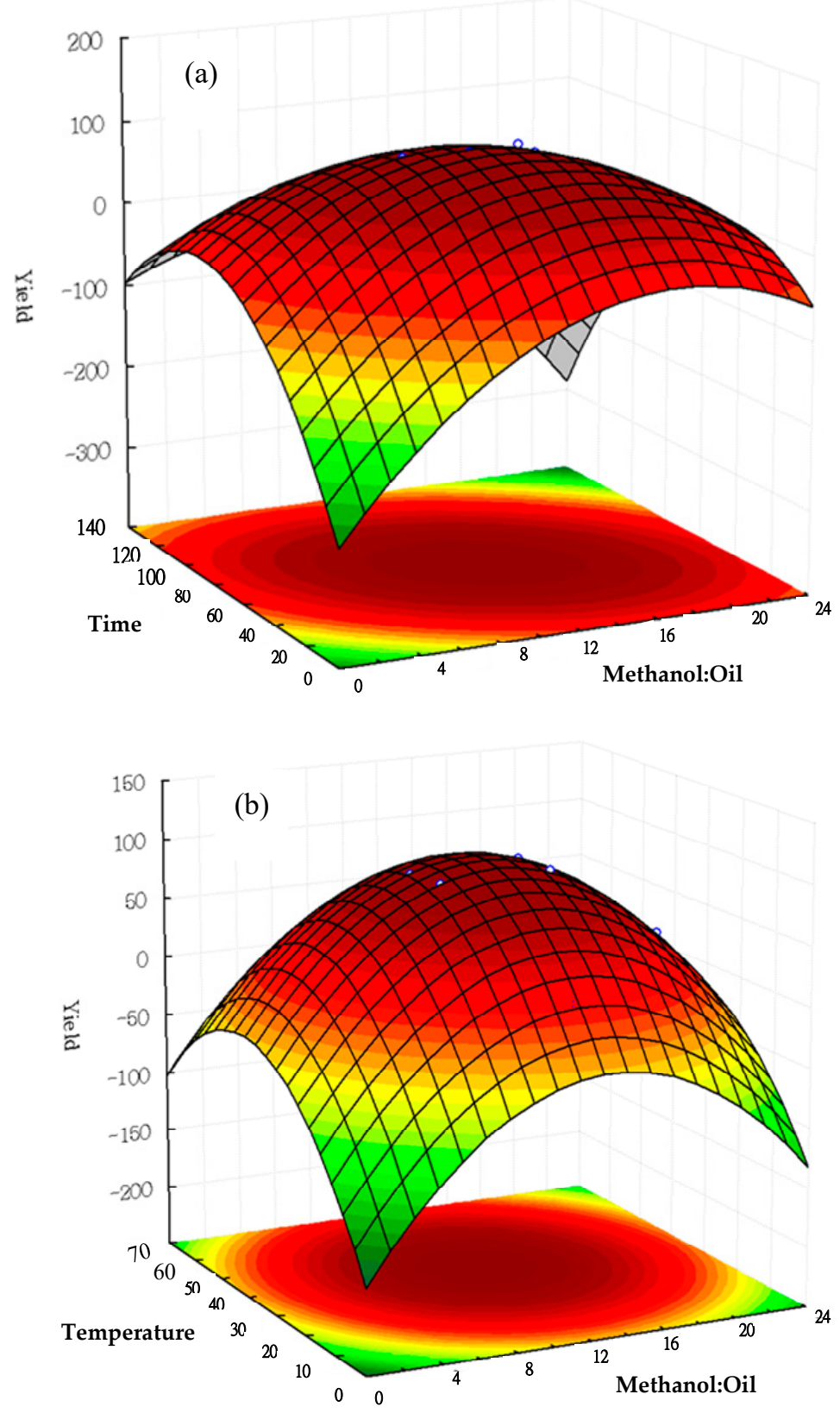

Figure 6. Response surface methodology on biodiesel production using 1:1 jatropha oil to castor oil as a feedstock. Plot (a) represents the significant interaction between reaction time ( $\mathrm{min}$ ) and methanol:oil ratio, the biodiesel yield is symbolized well in the plot. Plot (b) shows the temperature and methanol:oil ratio on the biodiesel yield.

\subsection{Catalyst Stability}

From a previous study in our group, the optimized operation point for homogeneous base catalyst needs seven minutes of microwave heating to achieve the maximum yield of biodiesel [45]. However, it can be difficult to separate the homogeneous catalyst from the products at the end of the transesterification reaction, which is usually done by membrane filtration. Therefore, as pointed out, industrial applications of a homogeneous base catalyst in biodiesel production may be expensive and impractical [30]. On the other hand, the catalyst used in this study, a magnetized heterogeneous base catalyst, readily solves the problem of separating the catalyst from the reaction products. It can be performed simply by using a magnet. However, the performance of a heterogeneous base catalyst 
can be relatively worse than a homogeneous base catalyst. The mass of catalyst recycled at the end of each set of ten consecutive experiments is shown in Figure 7. The mass of recycled catalyst at the end of the tenth test was only $3.2 \mathrm{wt} \%$ less than the initial mass. The results in Figure 7 show that magneto-separation can be an efficient way to collect and reuse the heterogeneous base catalyst. The figure also shows the yield of FAME obtained from the same experiment sequence, using the same batch of the catalyst. As the number of applications increased, the yield decreased slightly. However, as pointed out above, the amount of catalyst recycled at the end of each experiment was reduced, and this might have resulted in the reduced yield that was observed. Meanwhile, it is noted that the yield at the end of the tenth experiment was approximately $2.2 \mathrm{wt} \%$ lower than the first experiment. The figure verifies the durability and stability of the catalyst. The results in Figure 7 show that the proposed catalyst has a very stable and predictable performance, even after successive and repeated applications. Further improvements might render the catalyst suitable for large-scale industrial applications, replacing current generation homogeneous and heterogeneous catalysts in biodiesel production.
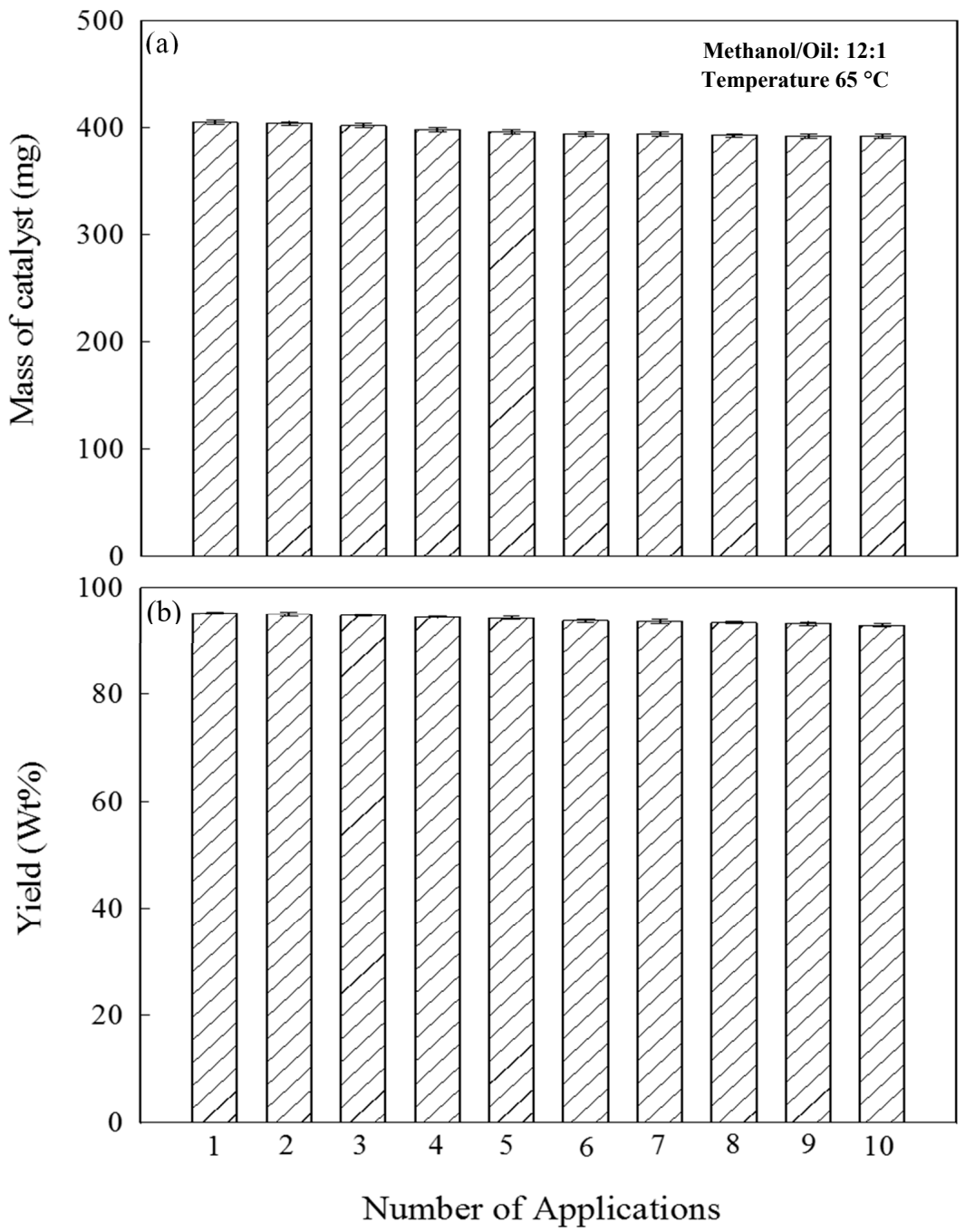

Figure 7. The mass of recycled catalyst (a) at the end of ten consecutive experiments and (b) the effects of catalyst stability on the yield of FAME.

\subsection{Comparison of Traditional and Microwave Heating}

Figure 8 compares the performance of microwave heating against conventional heating for the transesterification reaction. All cases in the figure were completed using a catalyst Ca:Fe ratio of 7:1, 
methanol/oil ratio of $12: 1$, and temperature of $65^{\circ} \mathrm{C}$. Comparing the data in the figure, the advantage of microwave heating is obvious, as it takes only $1 / 6$ th as long to achieve the maximum yield. The highest yield levels from both microwave heating and conventional heating are similar, at about $95 \%$. The extended reaction time may lead to the loss of methanol through evaporation, which results in a lower yield level. Furthermore, the extended reaction time may cause hydrolysis, which also causes the lower yield of FAME. The results in Figure 8 show that a microwave system can significantly lower the power consumption (due to shorted heating duration) in biodiesel production.

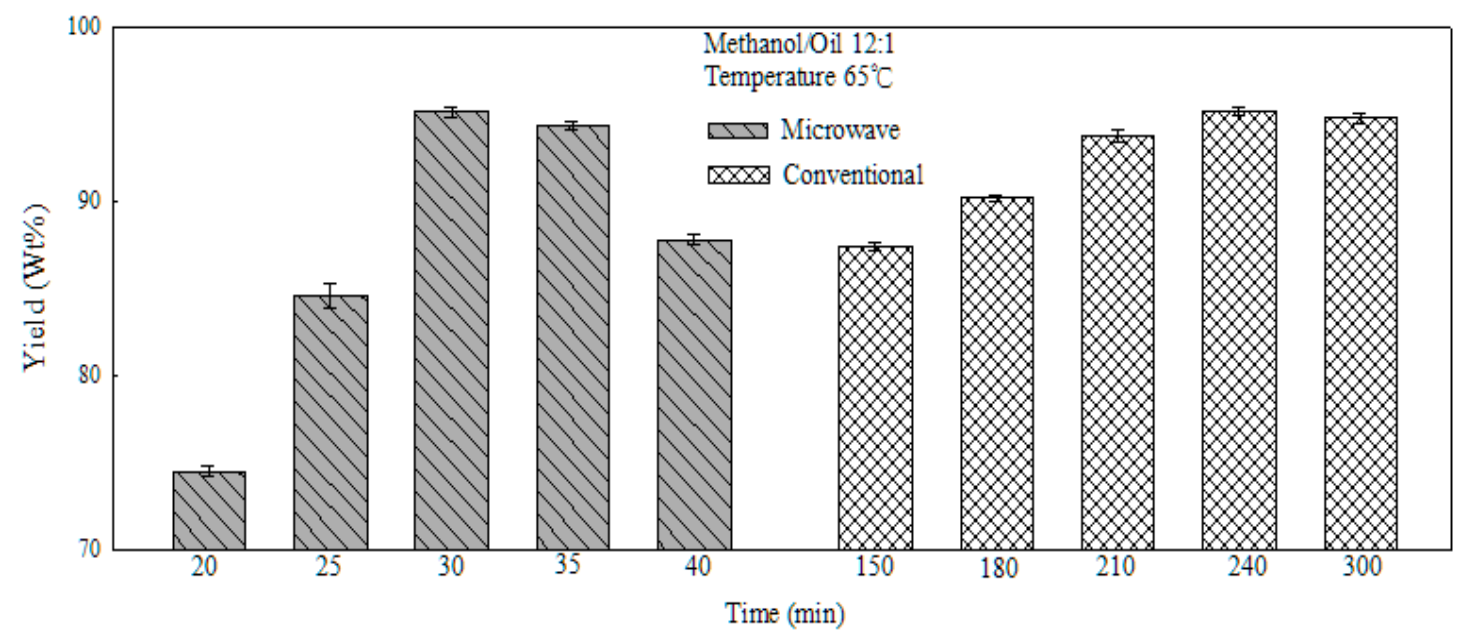

Figure 8. Comparison of biodiesel production using microwave heating and conventional heating.

\subsection{Effects of the Feedstock Oil}

Figure 9 displays the optimized yield of biodiesel using pure jatropha oil, pure castor oil, and the mixed feedstock oil. The reaction time was $35 \mathrm{~min}$ for the pure oils and $60 \mathrm{~min}$ for the mixture. The mixed feedstock oil resulted in the highest FAME yield of $95.2 \mathrm{wt} \%$. The yields of FAME are $91.7 \mathrm{wt} \%$ and $92.1 \mathrm{wt} \%$ for jatropha oil and castor oil, respectively. The lower yield of jatropha oil is most likely due to saponification because of high acidity, as a base catalyst was used in this study. For castor oil, a longer reaction time is needed as a result of high viscosity, which lowered the yield because of the hydrolysis resulting from the lengthy reaction duration.

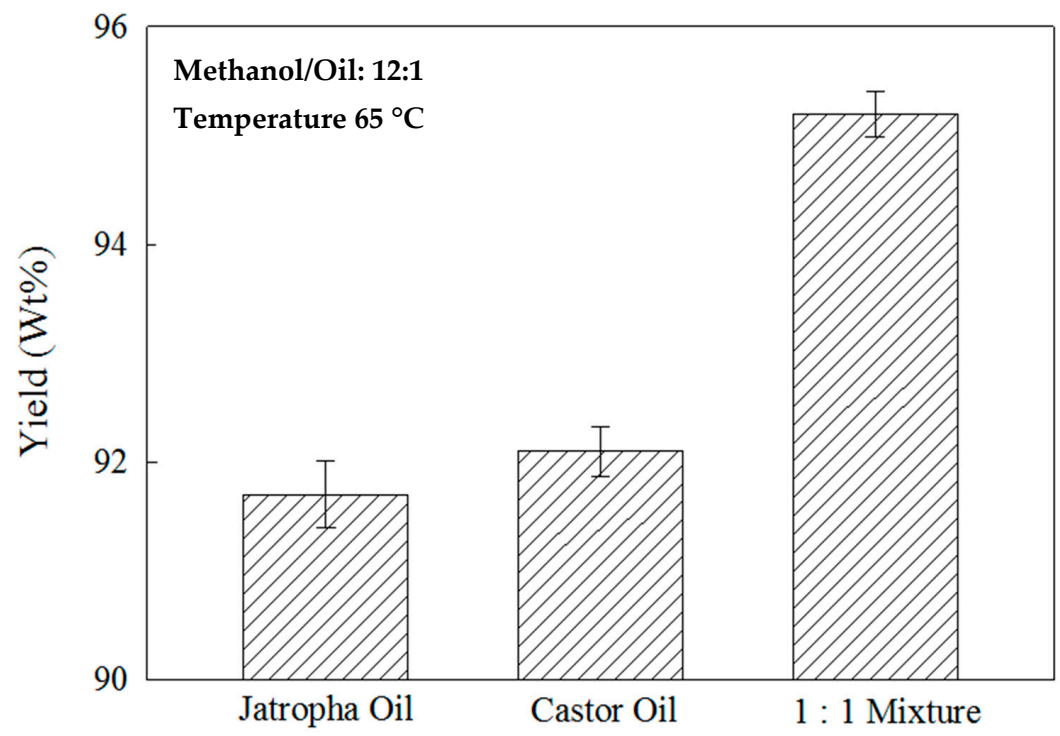

Figure 9. Effect of the feedstock oil on the yield of biodiesel with microwave heating. 


\section{Methodology}

\subsection{Materials for Experimentation}

In this study, jatropha oil and castor oil were used as the feedstocks for producing biodiesel with a microwave heating system. The raw materials, jatropha and castor oils, were purchased from Chinese Petroleum Corporation (CPC Corp., Chiayi City, Taiwan). Methanol was purchased from Burdick $\mathcal{E}$ Jackson (UNI-ONWARD Crop, New Taipei City, Taiwan). Iron oxide and soluble starch were sourced from Alfa Aesar (ECHO CHEMICAL CO., Ltd., Kaohsiung City, Taiwan). Both calcium chloride and sodium hydroxide were obtained from Sigma Inc. (UNI-ONWARD Crop., New Taipei City, Taiwan). The purity of all compounds is at least HPLC grade, and the purity of all solid chemicals is at least $99.5 \%$. Calcium hydroxide and nano-iron-oxide were synthesized before the experiments. The feedstock oils used in this study were tested for their saponification values and the molecular weights. The acidity of the feedstock oils, which reflects the quality (or freshness) of the oil, was measured as well. High acidity indicates that the oil product might become rancid. The properties of the feedstock oils used in this study are tabulated in Table 2 . The grain sizes were examined using a laser diffraction particle size analyzer (Malvern Mastersizer 3000, Malvern, WR, UK), and accurate particle size distributions for the grain structure of $\mathrm{Fe}_{3} \mathrm{O}_{4}$ and nano- $\mathrm{Ca}(\mathrm{OH})_{2} / \mathrm{Fe}_{3} \mathrm{O}_{4}$ are listed in Table 3.

\subsection{Synthesis and Recycling of the $\mathrm{Nano}-\mathrm{Ca}(\mathrm{OH})_{2} / \mathrm{Fe}_{3} \mathrm{O}_{4}$ Catalyst}

The heterogeneous base catalyst used in this study, nano- $\mathrm{Ca}(\mathrm{OH})_{2} / \mathrm{Fe}_{3} \mathrm{O}_{4}$, was synthesized by dissolving calcium chloride $\left(\mathrm{CaCl}_{2}\right)$ in distilled water. Then, iron oxide $\left(\mathrm{Fe}_{3} \mathrm{O}_{4}\right)$ nanoparticles and soluble starch were added to the solution. Sodium hydroxide $(\mathrm{NaOH})$ was titrated to the mixture at $65^{\circ} \mathrm{C}$ and stirred vigorously at $600 \mathrm{rpm}$. Calcium chloride reacted with sodium hydroxide and formed calcium hydroxide $\left(\mathrm{Ca}(\mathrm{OH})_{2}\right)$, a white powder suspended in the liquid. The $\mathrm{Ca}(\mathrm{OH})_{2}$ particles were subsequently loaded on the surface of the iron oxide particles. The molar ratio of $\mathrm{CaCl}_{2}$ to $\mathrm{Fe}_{3} \mathrm{O}_{4}$ was fixed at 7:1. Then, the as-produced nano- $\mathrm{Ca}(\mathrm{OH})_{2} / \mathrm{Fe}_{3} \mathrm{O}_{4}$ catalyst was cured at $65^{\circ} \mathrm{C}$ for $18 \mathrm{~h}$. It was then carefully washed with distilled water until the $\mathrm{pH}$ value of the effluent reached 7 before drying at $85^{\circ} \mathrm{C}$ for $24 \mathrm{~h}$.

The catalyst was recycled after each experiment by separating the catalyst from the reaction products using a magnet. The recycled catalyst was repeatedly washed with distilled water and isopropanol. It was then oven-dried before reuse. The magnet was wrapped with a plastic film (or any non-magnetic materials) to facilitate the separation of the catalyst from the magnet.

\subsection{Characterization of the Catalyst}

The characteristics and properties of the catalyst were examined and analyzed. A powder X-ray diffractometer (XRD; Siemens D5000, Munich, Germany) was used to study the purity of the catalyst. The morphologies of the nano- $\mathrm{Ca}(\mathrm{OH})_{2} / \mathrm{Fe}_{3} \mathrm{O}_{4}$ catalyst were measured by a FEI Quanta $400 \mathrm{~F}$ environmental scanning electronic microscope (ESEM; FEI Quanta 400 F, Hillsboro, OR, USA). The element composition of the catalyst was detected by an energy-dispersive $\mathrm{X}$-ray spectrometer (EDS; FEI Quanta 400 F, Hillsboro, OR, USA) that was mounted on the ESEM. The specific area was analyzed using a particle surface area and porosity analyzer.

\subsection{Transesterification for 1:1 Mixed Jatropha-Castor Oil Biodiesel with Methanol}

The raw castor oil and jatropha oil were filtered before charging them in the reaction furnace to remove impurities. The oils were subsequently pre-treated by heating at $105{ }^{\circ} \mathrm{C}$ for an hour to remove adhered water. After pre-treatment, the oils were cooled and filtered against any remaining particles and impurities. The oils were then mixed at a molar ratio of 1:1, to reduce the viscosity, and were stored in a tight-sealed container to prevent contact with air. The mixed oil will be known as the "mixed feedstock oil" hereafter. 
Previous research works indicated that catalysis can accelerate the transesterification reaction. However, the use of an acidic catalyst may cause corrosion in diesel engines. The problem can be prevented by using a base catalyst, such as nano- $\mathrm{Ca}(\mathrm{OH})_{2} / \mathrm{Fe}_{3} \mathrm{O}_{4}$. Dorado et al. concluded that there is an optimal amount of catalyst for transesterification [46]. If an excessive amount of catalyst is added, the contact area between the reactants would indeed be reduced and, therefore, lower the yield. From a previous study by our research group [45], the optimal amount of homogeneous catalyst was $1 \mathrm{wt} \%$ for experiments under similar conditions to those in this study. Taking into account that a heterogeneous base catalyst was used in this study, the amount of catalyst was increased to $2 \mathrm{wt} \%$. An APEX Atmospheric Microwave Synthesis and Extraction System from (PreeKem Scientific Instruments Co., Ltd., Shanghai, China) was used for the transesterification process. The system includes the following components: a condenser, stirrer (both mechanical and magnetic), and temperature controller. The effect of a catalyst dosage of $2 \mathrm{wt} \%$ was studied for transesterification under 1:1 mixed jatropha-castor oil, and was then added to the methanol solution at the desired methanol-oil ratio. The mixture was then charged in the microwave reactor for transesterification. The reaction was carried out at different temperatures, reaction durations, and methanol-oil ratios. The reactor contents were under rigorous stirring throughout the transesterification reaction to maintain contact between participating species. Once the reaction stopped, the catalyst was separated from the products with a magnet wrapped in plastic film. The products were then centrifuged for $5 \mathrm{~min}$ at $2500 \mathrm{rpm}$. After settling, the product mixture was separated into two layers with a less viscous top layer being the fatty acid methyl ester (FAME) and a thicker lower layer being the glycerol. A small amount of FAME was obtained from the top layer and washed thrice with distilled water and dried in an oven. The resulting substance was biodiesel, which was then analyzed by gas chromatography to evaluate its ester content.

\subsection{Product Analysis}

The analytic method of methyl ester content in this study followed Taiwan CNS15051 (Chinese National Standards). A GC (gas chromatography; GC-6890, Agilent, Santa Clara, CA, USA) system equipped with an FID (flame ionization detector) was used to determine the methyl ester content. The temperature of the injection port and detector were set at 250 and $260{ }^{\circ} \mathrm{C}$, respectively. The oven temperature was programmed to initiate at $50^{\circ} \mathrm{C}$ for $2 \mathrm{~min}$ and then the temperature was raised to $150{ }^{\circ} \mathrm{C}$ at a rate of $10^{\circ} \mathrm{C} \mathrm{min}^{-1}$, and held for $2 \mathrm{~min}$. The temperature was then raised to $200{ }^{\circ} \mathrm{C}$ at a rate of $4{ }^{\circ} \mathrm{C} \mathrm{min}-1$, held for $4 \mathrm{~min}$, and finally increased to $230{ }^{\circ} \mathrm{C}$ at a rate of $1{ }^{\circ} \mathrm{C} \mathrm{min}-1$ and held for $5 \mathrm{~min}$. The injection volume was $1 \mu \mathrm{L}$ in the splitless injection mode. The capillary column was an HP-INNOWAX $19091 \mathrm{~N}-133,30 \mathrm{~m} \times 0.25 \mathrm{~mm}$ I.D, and the film thickness was $0.25 \mu \mathrm{m}$. The split rate was 1:60. The velocity of the carrier gas (He) was set at $19 \mathrm{~cm} \mathrm{~s}^{-1}$. The GC/FID was calibrated with a diluted standard solution of $\mathrm{C}_{14}-\mathrm{C}_{24}$ compounds (37 Component FAME Mix-CRM47885; Supelco, Taipei City, Taiwan). The methyl ester content is defined as follows:

$$
\text { Methyl ester content }=\mathrm{C}=\left((\Sigma \mathrm{A})-\mathrm{A}_{\mathrm{EI}}\right) \times\left(\mathrm{A}_{\mathrm{EI}}\right)^{-1} \cdot\left(\mathrm{C}_{\mathrm{EI}} \times \mathrm{V}_{\mathrm{EI}}\right) \times \mathrm{m}^{-1} \times 100 \%
$$

where $\sum \mathrm{A}$ is the sum of the peak area of the fatty acid methyl ester from $\mathrm{C}_{14}$ to $\mathrm{C}_{24: 1} ; A_{E I}$ is the peak area of the internal standard, methyl heptadecanoate $\left(\mathrm{C}_{18} \mathrm{H}_{36} \mathrm{O}_{2}\right) ; C_{E I}$ is the concentration of methyl heptadecanoate $\left(\mathrm{mg} \mathrm{mL}^{-1}\right) ; V_{E I}$ is the volume of methyl heptadecanoate $\left(\mathrm{mL}^{-1}\right)$; and $\mathrm{m}$ is the mass of the input biodiesel $(\mathrm{g})$. The methyl ester yield is defined as follows:

$$
\text { Methyl ester yield }=\text { methyl ester content } \times \text { biodiesel yield }=\mathrm{C} \times \mathrm{W}_{\mathrm{B}} \times\left(\mathrm{W}_{\mathrm{oil}}\right)^{-1}
$$

where $\mathrm{C}$ is the methyl ester content (\%); $W_{B}$ is the weight of biodiesel production (g); and $W_{\text {oil }}$ is the weight of the initial amount of palm oil $(\mathrm{g})$. 


\subsection{Design of the Experiments}

Improving and optimizing the yield of biodiesel by using microwave heating is the main purpose of this study. The Central Composite Design (CCD) and Response Surface Methodology (RSM) were applied in the search for the optimized operation point. The response was the measured yield of biodiesel, as shown in Equation (1). The factors of concern were the catalyst Ca:Fe ratio (5:1, 6:1, 7:1, 8:1, and 9:1), methanol to oil molar ratio $(2: 1,9: 1,12: 1,15: 1$, and $22: 1)$, temperature $\left(10{ }^{\circ} \mathrm{C}, 60{ }^{\circ} \mathrm{C}\right.$, $65^{\circ} \mathrm{C}, 70^{\circ} \mathrm{C}$, and $\left.120^{\circ} \mathrm{C}\right)$, and reaction time $(6,30,35,40$, and $65 \mathrm{~min})$. Table 2 lists the test conditions corresponding to sixteen combinations of the methanol/oil ratio, heating temperature, and reaction time. Moreover, for each of the catalyst $\mathrm{Ca}$ :Fe ratios, eight experiments were conducted using different combinations of the methanol to oil molar ratio, temperature, and reaction time, corresponding to Runs 1 to 8 in Table 2.

\section{Conclusions}

The $\mathrm{Ca}(\mathrm{OH})_{2}$-loaded nano- $\mathrm{Fe}_{3} \mathrm{O}_{4}$ catalyst applied in this study can be separated from the reaction products easily with a magnet. Loading $\mathrm{Ca}(\mathrm{OH})_{2}$ onto $\mathrm{Fe}_{3} \mathrm{O}_{4}$ particles increases the specific surface area by almost $40 \%$, which enhances the catalytic activity. Microwave heating can reduce the reaction time by about $85 \%$ with a similar yield level for the mixed jatropha-castor oil. The experimental results indicate that the reaction temperature has a significant impact on the yield of methyl esters. Only 3\% of the catalyst was lost after ten successive applications, and the FAME yield was $2 \%$ lower at the tenth application. The optimum methyl ester yield was $95 \%$, using a catalyst with a Ca:Fe ratio of 7:1, temperature of $65^{\circ} \mathrm{C}$, methanol/oil ratio of 12:1, and reaction time of $35 \mathrm{~min}$. The catalyst was shown to be reusable and easily recyclable, and its activity was very stable. Only $2 \%$ of the catalyst was lost, and the yield was 3\% lower after ten successive applications. The solid, magnetic base catalyst could be easily separated from the reaction products which is one of the best catalysts available for improving the FAME yield of biodiesel.

Acknowledgments: The authors would like to thank Houng-Yung Chen's group (Institute of Marine Biology, National Sun Yat-sen University) for their help with the biodiesel analysis. This work was supported by the Ministry of Science and Technology under grant MOST 103-ET-E-110-001-ET.

Author Contributions: Ken-Lin Chang and Yuan-Chung Lin conceived and designed the experiments; Syu-Ruei Jhang, Way Lee Cheng, Shang-Cyuan Chen and Sung-Yuan Mao performed the experiments, analyzed the data.

Conflicts of Interest: The authors declare no conflict of interest.

\section{Nomenclature}

$\begin{array}{ll}\mathrm{CaCl}_{2} & \text { Calcium chloride } \\ \mathrm{Ca}(\mathrm{OH})_{2} & \text { Calcium Hydroxide } \\ \text { XRD } & \text { X-ray diffraction analysis } \\ \text { ESEM } & \text { Environmental scanning electron microscope } \\ \text { EDS } & \text { Energy Dispersive Spectroscopy }\end{array}$

\section{References}

1. Haas, M.J.; McAloon, A.J.; Yee, W.C.; Foglia, T.A. A process model to estimate biodiesel production costs. Bioresour. Technol. 2006, 97, 671-678. [CrossRef] [PubMed]

2. Knothe, G.; Van Gerpen, J.H.; Krahl, J. The Biodiesel Handbook; AOCS Press: Champaign, IL, USA, 2005.

3. Lin, Y.C.; Lee, W.J.; Hou, H.C. PAH emissions and energy efficiency of palm-biodiesel blends fueled on diesel generator. Atmos. Environ. 2006, 40, 3930-3940. [CrossRef]

4. Lin, Y.C.; Lee, W.J.; Wu, T.S.; Wang, C.T. Comparison of PAH and regulated harmful matter emissions from biodiesel blends and paraffinic fuel blends on engine accumulated mileage test. Fuel 2006, 85, 2516-2523. [CrossRef] 
5. Yuan, C.S.; Lin, H.Y.; Lee, W.J.; Lin, Y.C.; Wu, T.S.; Chen, K.F. A new alternative fuel for reduction of polycyclic aromatic hydrocarbon and particulate matter emissions from diesel engines. J. Air Waste Manag. Assoc. 2007, 57, 465-471. [CrossRef] [PubMed]

6. Lin, Y.C.; Tsai, C.H.; Yang, C.R.; Wu, C.J.; Wu, T.Y.; Chang-Chien, G.P. Effects on aerosol size distribution of polycyclic aromatic hydrocarbons from the heavy-duty diesel generator fueled with feedstock palm-biodiesel blends. Atmos. Environ. 2008, 42, 6679-6688. [CrossRef]

7. Lin, Y.C.; Liu, S.H.; Chen, Y.M.; Wu, T.Y. A new alternative paraffinic-palmbiodiesel fuel for reducing polychlorinated dibenzo-p-dioxin/dibenzofuran emissions from heavy-duty diesel engines. J. Hazard. Mater. 2011, 185, 1-7. [CrossRef] [PubMed]

8. Salamanca, M.; Mondragón, F.; Agudelo, J.R.; Santamaría, A. Influence of palm oil biodiesel on the chemical and morphological characteristics of particulate matter emitted by a diesel engine. Atmos. Environ. 2012, 62, 220-227. [CrossRef]

9. Sooknoi, T.; Danuthai, T.; Lobban, L.L.; Mallinson, R.G.; Resasco, D.E. Deoxygenation of methylesters over CsNaX. J. Catal. 2008, 258, 199-209. [CrossRef]

10. United States Environmental Protection Agency. A Comprehensive Analysis of Biodiesel Impacts on Exhaust Emissions Draft Technical Report; EPA420-P-02-001; United States Environmental Protection Agency: Washington, DC, USA, 2002.

11. Araujo, V.K.W.S.; Hamacher, S.; Scavarda, L.F. Economic assessment of biodiesel production from waste frying oils. Bioresour. Technol. 2010, 101, 4415-4422. [CrossRef] [PubMed]

12. Dmytryshyn, S.; Dalai, A.; Chaudhari, S.; Mishra, H.; Reaney, M. Synthesis and characterization of vegetable oil derived esters: Evaluation for their diesel additive properties. Bioresour. Technol. 2004, 92, 55-64. [CrossRef] [PubMed]

13. Vicente, G.; Martínez, M.; Aracil, J. Integrated biodiesel production: A comparison of different homogeneous catalysts systems. Bioresour. Technol. 2004, 92, 297-305. [CrossRef] [PubMed]

14. Tang, S.; Wang, L.; Zhang, Y.; Li, S.; Tian, S.; Wang, B. Study on preparation of $\mathrm{Ca} / \mathrm{Al} / \mathrm{Fe}_{3} \mathrm{O}_{4}$ magnetic composite solid catalyst and its application in biodiesel transesterification. Fuel Process. Technol. 2012, 95, 84-89. [CrossRef]

15. Bak, Y.C.; Choi, J.H.; Kim, S.B.; Kang, D.W. Production of bio-diesel fuels by transesterification of rice bran oil. Korean J. Chem. Eng. 1996, 13, 242-245. [CrossRef]

16. Freedman, B.; Pryde, E.; Mounts, T. Variables affecting the yields of fatty esters from transesterified vegetable oils. J. Am. Oil Chem. Soc. 1984, 61, 1638-1643. [CrossRef]

17. Apostolakou, A.; Kookos, I.; Marazioti, C.; Angelopoulos, K. Techno-economic analysis of a biodiesel production process from vegetable oils. Fuel Process. Technol. 2009, 90, 1023-1031. [CrossRef]

18. Ma, F.; Hanna, M.A. Biodiesel production: A review. Bioresour. Technol. 1999, 70, 1-15. [CrossRef]

19. Fukuda, H.; Kondo, A.; Noda, H. Biodiesel fuel production by transesterification of oils. J. Biosci. Bioeng. 2001, 92, 405-416. [CrossRef]

20. Brito, A.; Borges, M.; Otero, N. Zeolite $\mathrm{Y}$ as a heterogeneous catalyst in biodiesel fuel production from used vegetable oil. Energy Fuels 2007, 21, 3280-3283. [CrossRef]

21. Granados, M.L.; Poves, M.Z.; Alonso, D.M.; Mariscal, R.; Galisteo, F.C.; Moreno-Tost, R.; Santamaría, J.; Fierro, J. Biodiesel from sunflower oil by using activated calcium oxide. Appl. Catal. B Environ. 2007, 73, 317-326. [CrossRef]

22. Kawashima, A.; Matsubara, K.; Honda, K. Acceleration of catalytic activity of calcium oxide for biodiesel production. Bioresour. Technol. 2009, 100, 696-700. [CrossRef] [PubMed]

23. Son, S.M.; Kusakabe, K. Transesterification of sunflower oil in a countercurrent trickle-bed reactor packed with a CaO catalyst. Chem. Eng. Process. Process Intensif. 2011, 50, 650-654. [CrossRef]

24. Umdu, E.S.; Tuncer, M.; Seker, E. Transesterification of Nannochloropsis oculata microalga's lipid to biodiesel on $\mathrm{Al}_{2} \mathrm{O}_{3}$ supported $\mathrm{CaO}$ and $\mathrm{MgO}$ catalysts. Bioresour. Technol. 2009, 100, 2828-2831. [CrossRef] [PubMed]

25. Wan, T.; Yu, P.; Wang, S.; Luo, Y. Application of sodium aluminate as a heterogeneous base catalyst for biodiesel production from soybean oil. Energy Fuels 2009, 23, 1089-1092. [CrossRef]

26. Liu, X.; Piao, X.; Wang, Y.; Zhu, S.; He, H. Calcium methoxide as a solid base catalyst for the transesterification of soybean oil to biodiesel with methanol. Fuel 2008, 87, 1076-1082. [CrossRef]

27. Di Serio, M.; Cozzolino, M.; Giordano, M.; Tesser, R.; Patrono, P.; Santacesaria, E. From Homogeneous to Heterogeneous Catalysts in Biodiesel Production. Ind. Eng. Chem. Res. 2007, 46, 6379-6384. 
28. Ying, M.; Chen, G. Study on the production of biodiesel by magnetic cell biocatalyst based on lipase-producing Bacillus subtilis. Appl. Biochem. Biotechnol. 2007, 137, 793-803. [PubMed]

29. Xie, W.; Ma, N. Immobilized lipase on $\mathrm{Fe}_{3} \mathrm{O}_{4}$ nanoparticles as biocatalyst for biodiesel production. Energy Fuels 2009, 23, 1347-1353. [CrossRef]

30. Hu, S.; Guan, Y.; Wang, Y.; Han, H. Nano-magnetic catalyst $\mathrm{KF} / \mathrm{CaO}-\mathrm{Fe}_{3} \mathrm{O}_{4}$ for biodiesel production. Appl. Energy 2011, 88, 2685-2690. [CrossRef]

31. Liu, C.; Lv, P.; Yuan, Z.; Yan, F.; Luo, W. The nanometer magnetic solid base catalyst for production of biodiesel. Renew. Energy 2010, 35, 1531-1536. [CrossRef]

32. Dai, Y.M.; Wu, J.S.; Chen, C.C.; Chen, K.C. Evaluating the optimum operating parameters on transesterification reaction for biodiesel production over a $\mathrm{LiAlO}_{2}$ catalyst. Chem. Eng. J. 2015, 280, 370-376. [CrossRef]

33. Dai, Y.M.; Kao, I.H.; Chen, C.C. Evaluating the optimum operating parameters of biodiesel production process from soybean oil using the $\mathrm{Li}_{2} \mathrm{TiO}_{3}$ catalyst. J. Taiwan Inst. Chem. Eng. 2017, 70, 260-266. [CrossRef]

34. Azcan, N.; Danisman, A. Alkali catalyzed transesterification of cottonseed oil by microwave irradiation. Fuel 2007, 86, 2639-2644. [CrossRef]

35. Suppalakpanya, K.; Ratanawilai, S.; Tongurai, C. Production of ethyl ester from crude palm oil by two-step reaction with a microwave system. Fuel 2010, 89, 2140-2144. [CrossRef]

36. Suppalakpanya, K.; Ratanawilai, S.; Tongurai, C. Production of ethyl ester from esterified crude palm oil by microwave with dry washing by bleaching earth. Appl. Energy 2010, 87, 2356-2359. [CrossRef]

37. Koberg, M.; Abu-Much, R.; Gedanken, A. Optimization of bio-diesel production from soybean and wastes of cooked oil: Combining dielectric microwave irradiation and a SrO catalyst. Bioresour. Technol. 2011, 102, 1073-1078. [CrossRef] [PubMed]

38. Knothe, G. Dependence of biodiesel fuel properties on the structure of fatty acid alkyl esters. Fuel Process. Technol. 2005, 86, 1059-1070. [CrossRef]

39. Vicente, G.; Martínez, M.; Aracil, J.; Esteban, A. Kinetics of sunflower oil methanolysis. Ind. Eng. Chem. Res. 2005, 44, 5447-5454. [CrossRef]

40. Moser, B.R. Biodiesel production, properties, and feedstocks. In Vitro Cell. Dev. Biol. Plant 2009, 45, $229-266$. [CrossRef]

41. Pandey, V.C.; Singh, K.; Singh, J.S.; Kumar, A.; Singh, B.; Singh, R.P. Jatropha curcas: A potential biofuel plant for sustainable environmental development. Renew. Sustain. Energy Rev. 2012, 16, 2870-2883. [CrossRef]

42. Kaushik, N.; Kumar, K.; Kumar, S.; Kaushik, N.; Roy, S. Genetic variability and divergence studies in seed traits and oil content of Jatropha (Jatropha curcas L.) accessions. Biomass Bioenergy 2007, 31, 497-502. [CrossRef]

43. Scholz, V.; da Silva, J.N. Prospects and risks of the use of castor oil as a fuel. Biomass Bioenergy 2008, 32, 95-100. [CrossRef]

44. Eevera, T.; Rajendran, K.; Saradha, S. Biodiesel production process optimization and characterization to assess the suitability of the product for varied environmental conditions. Renew. Energy 2009, 34, $762-765$. [CrossRef]

45. Lin, Y.C.; Yang, P.M.; Chen, S.C.; Lin, J.F. Improving biodiesel yields from waste cooking oil using ionic liquids as catalysts with a microwave heating system. Fuel Process. Technol. 2013, 115, 57-62. [CrossRef]

46. Dorado, M.; Ballesteros, E.; Arnal, J.; Gomez, J.; Lopez, F. Exhaust emissions from a Diesel engine fueled with transesterified waste olive oil. Fuel 2003, 82, 1311-1315. [CrossRef]

(C) 2017 by the authors. Licensee MDPI, Basel, Switzerland. This article is an open access article distributed under the terms and conditions of the Creative Commons Attribution (CC BY) license (http://creativecommons.org/licenses/by/4.0/). 